\title{
KINETIC AND ISOTHERM STUDY OF CUPPER ADSORPTION FROM AQUEOUS SOLUTION USING WASTE EGGSHELL
}

\author{
Ayben Polat, Sukru Aslan \\ Department of Environmental Engineering, Cumhuriyet University, 58140 Sivas, Turkey
}

Submitted 30 Jan. 2013; accepted 11 Nov. 2013

\begin{abstract}
The sorption of $\mathrm{Cu}^{2+}$ ions from aqueous solutions by eggshell was investigated in a batch experimental system with respect to the temperature, initial $\mathrm{Cu}^{2+}$ concentrations, $\mathrm{pH}$, and biosorbent doses. The adsorption equilibrium was well described by the Langmuir isotherm model with the maximum adsorption capacity of $5.05 \mathrm{mg} \mathrm{Cu}{ }^{2+} / \mathrm{g}$ eggshell at $25^{\circ} \mathrm{C}$. The value of $\mathrm{q}_{e}$ increased with increasing the temperature while also increases the release of $\mathrm{Ca}^{2+}$ and $\mathrm{HCO}_{3}^{-}$ions from the eggshell. The highest sorption of $\mathrm{Cu}^{2+}$ onto the waste eggshell was determined at the initial $\mathrm{pH}$ value of 4.0. The results confirming that the adsorption reaction of $\mathrm{Cu}^{2+}$ on the eggshell was thought to be endothermic. A comparison of the kinetic models such as pseudo first and second-order kinetics, intraparticle diffusion, and Elovich on the sorption rate demonstrated that the system was best described by the pseudo second-order kinetic model.
\end{abstract}

Keywords: eggshells, adsorption, copper, water cleaning technologies.

Reference to this paper should be made as follows: Polat, A.; Aslan, S. 2014. Kinetic and isotherm study of cupper adsorption from aqueous solution using waste eggshell, Journal of Environmental Engineering and Landscape Management 22(02): 132-140. http://dx.doi.org/10.3846/16486897.2013.865631

\section{Introduction}

Industrial wastewaters contained various kinds of pollutants including heavy metals are commonly produced from many industrial processes. High concentrations of heavy metals affect negatively human, animal and vegetation in the water body. Because of unique characteristics of heavy metals, which are non-biodegradable and accumulated by living organisms, are the main environmental concerns (Ghazy et al. 2011).

Treatment of the wastewater including heavy metal ions became particularly difficult due to implementation of more restrict law regulations that control the concentration of pollutants in effluents discharged into waters and soil on the level lower than $1 \mathrm{mg} / \mathrm{kg}$ (Chojnacka 2005). The traditional treatment processes such as chemical precipitation and coagulation-flocculation for the removal of metal ions became inefficient to achieve below this concentration.

Several methods such as ion exchange, solvent extraction, phytoextraction, ultrafiltration, reverse osmosis, and adsorption have been widely used in order to remove heavy metals from industrial wastewaters. However, adsorption method is widely applied to eliminate heavy metals due to the some limitations like requirements of pretreatments, low removal efficiency and high capital cost of the other methods (Jai et al. 2007).

The application of adsorption is one of the effective, simple and low cost methods to remove low concentration heavy metal from industrial wastewater. Low cost sorbents are investigated for heavy metal elimination. The most frequently studied biosorbents are bacteria, fungi, and algae (Yeddou, Bensmaili 2007), grape stalks, crop milling waste, olive stone, sawdust (Zheng et al. 2007; Ozacar, Sengil 2005), peanut hull pellets, dried sunflower leaves, sugar beet pulp, capsicum annuum seeds (Slijvic et al. 2009), fish bones (Kizilkaya et al. 2010), and bone char (Cheung et al. 2000).

One cheap and easily available material having possibilities as suitable sorbent for heavy metal is eggshell. Due to their low cost and high calcium content, after these materials have been expended, they can be disposed without

Corresponding author: Sukru Aslan

E-mail: saslan@cumhuriyet.edu.tr 
expensive regeneration. Disposal of eggshells is also a serious problem for egg processing industries due to stricter environmental regulations and high landfill costs (Rao et al. 2010).

Copper is considered as one of the most toxic metal and poses a potential threat to the human health and environment, even at low concentrations (Ahmad et al. 2010). However, low concentrations of cupper is essential for living organisms and additionally deficiency of it may cause effects on human health like, anemia osteoporosis, decreased glucose tolerance, arthritis, cardiac arrhythmias and neurological problems. On the contrary, high concentrations of cupper causes toxicity, as the redox properties, essential for its function in excess copper in cells causes cuproenzymes, can also result in marked reactive oxygen species formation that can damage lipids, nucleic acids and proteins (Sljivic et al. 2009). Because of the toxic effects on the living organisms, cupper containing wastewaters from industries require treatment before their discharge into the environment.

The main objective of the experimental study was to investigate the adsorption of $\mathrm{Cu}^{2+}$ ions in the synthetic wastewater by using waste eggshells. The removal efficiency of $\mathrm{Cu}^{2+}$ on the eggshell was investigated as a function of temperature, $\mathrm{pH}$, contact time, initial $\mathrm{Cu}^{2+}$ concentrations, and adsorbent doses. Various models were applied to determine the adsorption isotherms with the best fit to the experimental data. The kinetic models, pseudo first and second order kinetics, intraparticle diffusion, and Elovich were applied in order to investigate the mechanisms of eggshell sorption.

\section{Materials and methods}

\subsection{Preparation of eggshell}

The chicken eggshells were collected from bakeries in Sivas, Turkey. After the eggshells were rinsed several times with tap and distilled water to remove impurities like organics and salts, it was dried at $60{ }^{\circ} \mathrm{C}$ for 24 hours in an oven. The eggshells were crushed and screened through a set of sieves to get the size of 106-250 $\mu \mathrm{m}$.

\subsection{Sorption studies}

All solutions were prepared from analytical reagent chemicals. The synthetic solutions were prepared by diluting $\mathrm{Cu}^{2+}$ standard stock solutions $(250 \mathrm{mg} / \mathrm{L})$ obtained by dissolving $\mathrm{CuCl}_{2}$ in the distilled water. Fresh dilutions of the synthetic wastewater were used in the experiments.

The sorption studies of $\mathrm{Cu}^{2+}$ from aqueous solution onto the eggshells were carried out using batch equilibrium techniques. Experiments were performed in $250 \mathrm{~mL}$ Erlenmeyer flasks containing $\mathrm{Cu}^{2+}$ and eggshells. $\mathrm{Cu}^{2+}$ analyses were performed in the initial solutions and clear samples at the end of batch tests. A sample of $0.25 \mathrm{~g}$ eggshell was added to $100 \mathrm{~mL}$ solution which was contained desired concentrations of $\mathrm{Cu}^{2+}$.

The effects of experimental parameters such as, initial $\mathrm{Cu}^{2+}$ ion concentration (10-50 mg/L), $\mathrm{pH}(2.0-5.0)$, adsorbent dosage $(0.05-0.5 \mathrm{~g} / \mathrm{L})$ and temperature $(25-$ $50{ }^{\circ} \mathrm{C}$ ) on the removal of $\mathrm{Cu}^{2+}$ ions were studied. Initial $\mathrm{pH}$ of the solutions were adjusted using $\mathrm{H}_{2} \mathrm{SO}_{4}$ or $\mathrm{NaOH}$ solutions. Various concentrations of $\mathrm{Cu}^{2+}$ solutions (15,

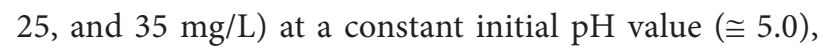
and adsorbent dosage $(2.5 \mathrm{~g} / \mathrm{L})$ were used for the kinetic experiments. The batch units were agitated in an orbital incubator shaker (Gerhardt) for a contact time varied in the range $0-2880 \mathrm{~min}$ at a speed of $150 \mathrm{rpm}$ at $25{ }^{\circ} \mathrm{C}$. The samples were then centrifuged in NUVE Centrifuge NF800 at $4000 \mathrm{rpm}$ for $10 \mathrm{~min}$ to separate the solution from the adsorbent.

Calcination was carried out by increasing the temperature of furnace (REF 150 model, REFSAN) at a rate of $4{ }^{\circ} \mathrm{C} / \mathrm{min}$ to $1000^{\circ} \mathrm{C}$ after crushing the sample.

The initial and final concentrations of $\mathrm{Cu}^{2+}$ in the aqueous solutions were determined by using a Merck Spectraquant analytical $\mathrm{Cu}^{2+}$ kit (14767) with a Merck photometer PHARO100. The other measurements such as alkalinity, $\mathrm{Ca}^{2+}, \mathrm{HCO}^{-}$, etc. were carried out using the APHA (1998).

\subsection{Calculations}

The amounts of $\mathrm{Cu}^{2+}$ sorbed by eggshells were calculated from the differences between $\mathrm{Cu}^{2+}$ quantity added to the sorbent and $\mathrm{Cu}^{2+}$ concentration of the supernatant by using following equation:

$$
\mathrm{q}_{\mathrm{e}}(\mathrm{mg} \mid \mathrm{g})=\left(\mathrm{C}_{\mathrm{o}}-\mathrm{C}_{\mathrm{e}}\right)(\mathrm{mg} \mid \mathrm{L}) \times \mathrm{V} / \mathrm{M}(\mathrm{mL} \mid \mathrm{g}),
$$

The efficiency of $\mathrm{Cu}^{2+}$ removal (E) (\%) is calculated by using Eqn (2):

$$
\mathrm{E}(\%)=\frac{\mathrm{C}_{0}-\mathrm{C}_{\mathrm{e}}}{\mathrm{C}_{0}} \times 100,
$$

where: $\mathrm{q}_{\mathrm{e}}(\mathrm{mg} / \mathrm{g})$ is the maximum amount of $\mathrm{Cu}^{2+}$ adsorbed at equilibrium; $\mathrm{C}_{\mathrm{o}}$ and $\mathrm{C}_{\mathrm{e}}(\mathrm{mg} / \mathrm{L})$ are the initial and equilibrium concentrations of $\mathrm{Cu}^{2+}$ in the solution, $\mathrm{M}$ is the mass of eggshell ( $\mathrm{g}$ ); and V is the volume of the solution, respectively.

Sorption experiments were performed in triplicate and the average values of samples were presented. Also, blank samples (without $\mathrm{Cu}^{2+}$ ) were used to compare the results through all batch procedures. Data presented are the mean values from the experiments, standard deviation $(\leq 6 \%)$ and error bars are indicated in figures.

\section{Results and discussion}

The surface of adsorbent characterized by scanning electron microscopy (SEM) was determined in the 


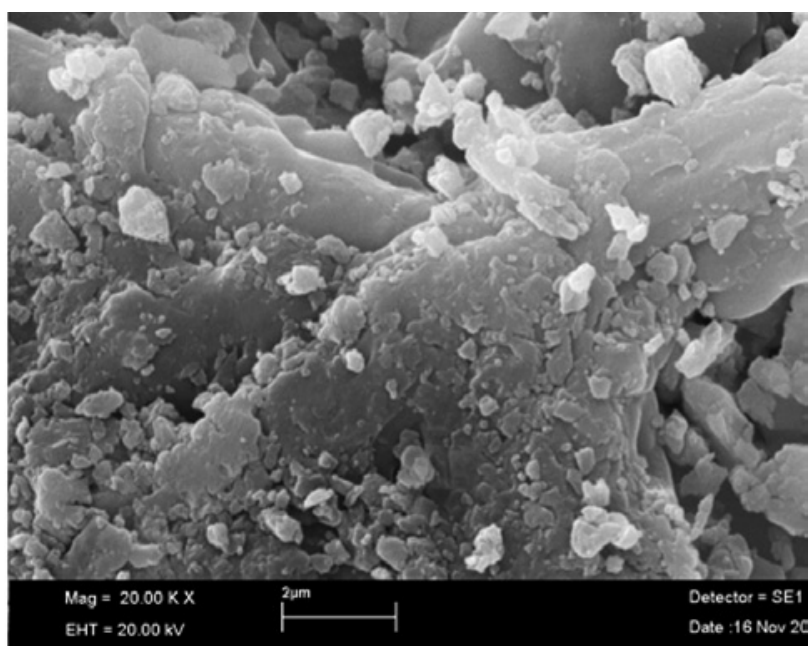

Fig. 1. SEM micrograph of waste eggshell

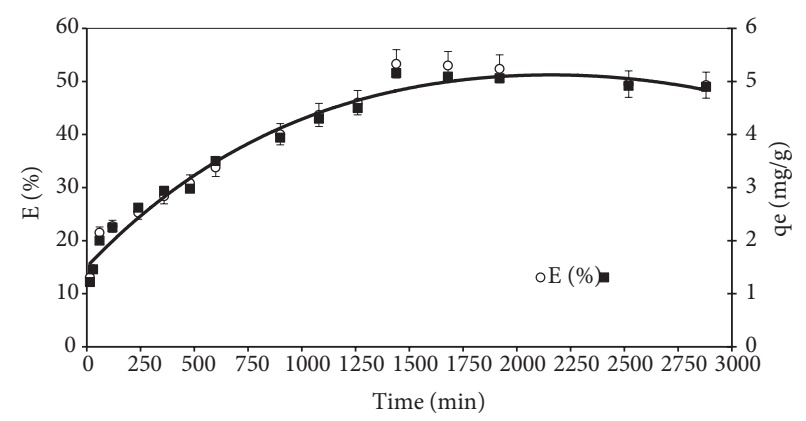

Fig. 2. Effect of contact time on $\mathrm{Cu}^{2+}$ sorption onto waste eggshell

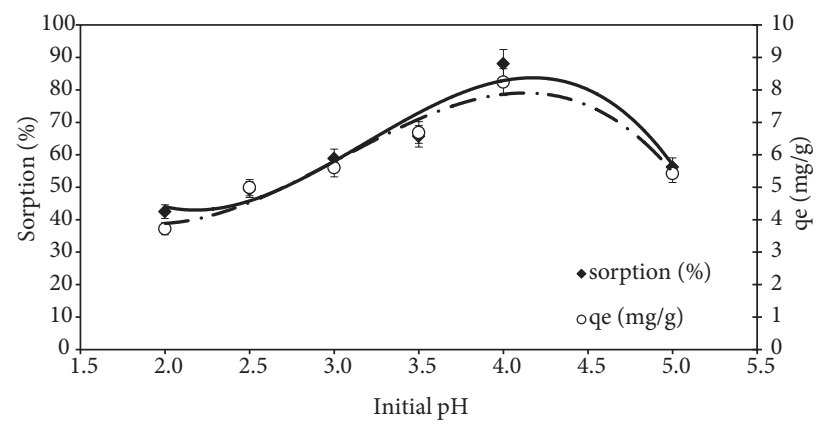

Fig. 3. Effect of initial $\mathrm{pH}$ on $\mathrm{Cu}^{2+}$ sorption onto eggshell

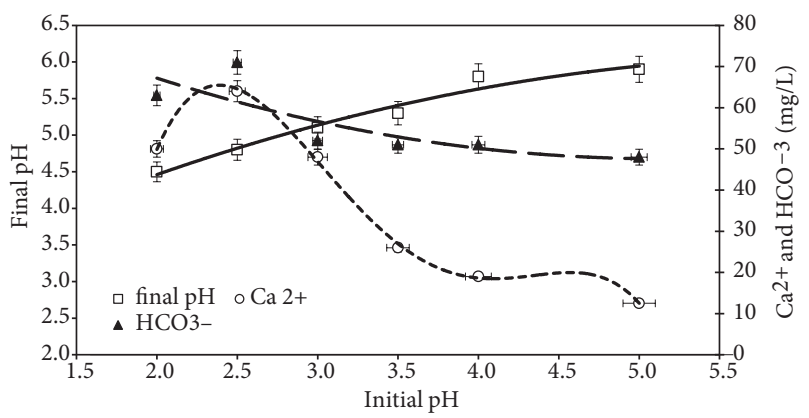

Fig. 4. Effect of initial $\mathrm{pH}$ on the release of $\mathrm{Ca}^{2+}$ and $\mathrm{HCO}^{3-}$ ions from the eggshell laboratory of Kayseri Teknokent. SEM micrograph shows that eggshell has considerable numbers of pores where the $\mathrm{Cu}^{2+}$ ions can be adsorbed (Fig. 1).

\subsection{Effect of contact time}

The effects of contact time for the initial concentration of $25.0 \mathrm{mg} \mathrm{Cu}^{2+} / \mathrm{L}$ were studied. The data obtained from the experiments showed that the contact time of $1440 \mathrm{~min}$ was sufficient to achieve equilibrium, because the adsorption reached a plateau at this time (Fig. 2). At this point the highest $\mathrm{Cu}^{2+}$ sorption efficiency (about 55\%) and adsorption value $\left(\mathrm{q}_{\mathrm{e}}=5.2 \mathrm{mg} / \mathrm{g}\right)$ were achieved. Further increase the contact time, the sorption did not take place. Due to the active sites of the eggshell availability and the highest driving force for the mass transfer, rapid $\mathrm{Cu}^{2+}$ uptake onto the sorbent was observed at the beginning (zero to $60 \mathrm{~min}$ ) of the sorption experiments. After this period, $\mathrm{Cu}^{2+}$ sorption was slower because of the occupancy of eggshell active sites and the lower concentrations of $\mathrm{Cu}^{2+}$ in the solution. Long mixing time was necessary in order to achieve the equilibrium time, due to the removal rate of $\mathrm{Cu}^{2+}$ was quite slow.

\subsection{Copper sorption at different initial solution $\mathbf{p H}$}

The acidity of solution is an important parameter for the sorption of heavy metals from aqueous solutions since the value of $\mathrm{pH}$ is responsible for protonation of metal binding sites, calcium carbonate solubility and $\mathrm{Cu}^{2+}$ speciation in the solution (Chojnacka 2005). The uptake of $\mathrm{Cu}^{2+}$ was investigated as the function of $\mathrm{pH}$ in the range of 2.0 to 5.0 with an increment of $0.5 \mathrm{pH}$ units.

Sorption of $\mathrm{Cu}^{2+}$ after interaction of $\mathrm{Cu}^{2+}$ and eggshell sorbents are presented in Figure 3. It was found that $\mathrm{Cu}^{2+}$ uptake by eggshells was a function of initial solution $\mathrm{pH}$. The lowest adsorption efficiency of $42.5 \%$ was observed at the $\mathrm{pH}$ value of 2.0. Increasing the $\mathrm{pH}$ value from 2.0 to 4.0 , sorption capacities $\left(\mathrm{q}_{\mathrm{e}}\right)$ and the removal efficiencies of $\mathrm{Cu}^{2+}$ increased significantly from $3.7 \mathrm{mg} / \mathrm{g}$ to $8.2 \mathrm{mg} / \mathrm{g}$ and $42.5 \%$ to $88 \%$ respectively. Further increase the $\mathrm{pH}$ value to 5.0, the $\mathrm{q}_{\mathrm{e}}$ value and removal efficiency decreases to about $5.4 \mathrm{mg} / \mathrm{g}$ and $56 \%$, respectively. The ionization degree of heavy metal and the surface property of the eggshell may be affected by the $\mathrm{pH}$. The same experimental results were also observed by Li and Wua (2010) and Ahmad et al. (2010). The optimum initial $\mathrm{pH}$ value for $\mathrm{Cu}^{2+}$ sorption by eggshell was determined to be 4.0. This results are expected as it is established that eggshell operate more efficiently under acidic conditions (Chojnacka 2005; Rao et al. 2010).

Experimental results showed that all the studied initial $\mathrm{pH}$ values were gradually increased and the highest final $\mathrm{pH}$ of about 6.0 was determined at the end of experiments (Fig. 4). Due to the release of $\mathrm{HCO}_{3}^{-}$ions from the eggshells, the $\mathrm{pH}$ in the solutions increased. As can be 
seen in the Figure 4 that the initial pHs significantly affects the release of $\mathrm{Ca}^{2+}$ and $\mathrm{HCO}_{3}^{-}$ions from the eggshell.

The chemical composition of eggshell was mainly calcium carbonate (Jai et al. 2007; Tsai 2006, 2008; Arunlertaree et al. 2007). In order to determine the $\mathrm{CaO}$ contents of the eggshell, calcinations experiments were carried out. The following reaction was happened in the calcinations (Zhang et al. 2011):

$$
\mathrm{CaCO}_{3} \rightarrow \mathrm{CaO}+\mathrm{CO}_{2} \uparrow \text {. }
$$

After calcinations of $550 \mathrm{~g}$ pre-treated eggshell, the sample weight was $300 \mathrm{~g}$ and corresponding mass loss was as $45.5 \%$. As most of the impurities such as organics and humidity were removed by the pretreatment process, it was assumed that a major composition (55.5\%) of the eggshell was identified as $\mathrm{CaO}$ when the temperature was ascending to $1000{ }^{\circ} \mathrm{C}$. A similar result was determined by Jai et al. (2007).

The chemical composition (by weight) of by-products eggshell has been reported as follows $\mathrm{CaCO}_{3}$ (94\%), magnesium carbonate $(1 \%)$, calcium phosphate $(1 \%)$, and organic matter (4\%) (Tsai 2008). The principal components of eggshell are $\mathrm{CaCO}_{3}$ and $\mathrm{HCO}_{3}^{-}, \mathrm{Ca}^{2+}, \mathrm{CaHCO}_{3}^{+}$, and $\mathrm{CaHO}^{+}$. They are formed in the solution and their proportion is dependent on the $\mathrm{pH}$ value (Ghazy et al. 2011).

It was expected that any water equilibrated with the eggshell became basic that confirmed with following mechanisms (Arunlertaree et al. 2007):

$$
\begin{aligned}
& \mathrm{CaCO}_{3} \leftrightarrow \mathrm{Ca}^{2+}+\mathrm{CO}_{3}^{2-} ; \\
& \mathrm{CO}_{3}^{2-} \leftrightarrow \mathrm{HCO}_{3}^{-}+\mathrm{OH}^{-} .
\end{aligned}
$$

As can be seen in the Eqn (4), the solution has become more basic due to the hydrolysis reaction of $\mathrm{CaCO}_{3}$ which gives $\mathrm{OH}^{-}$and $\mathrm{Ca}^{2+}$ content of the solution is also increased.

In general, sorption of divalent metal cations on metal oxides, hydroxides and oxyhydroxides is known to be promoted by increasing $\mathrm{pH}$. When divalent metal cations adsorb on these materials, the cations undergo a reaction with a surface hydroxyl group (Kuh, Kim 2000). Adsorption or precipitation mechanisms involve characteristic reactions of some metals with $\mathrm{CaO}$ and $\mathrm{MgO}$ surfaces, with adsorption occurring at low concentration of metals solution, and precipitation dominating at high concentrations (Pehlivan et al. 2009). Carbonates formed by $\mathrm{CaCO}_{3}$ dissolution increase the $\mathrm{pH}$ values in the solution and therefore may be formation of precipitate form of cupper precipitate near the surface of eggshell and then these forms adsorb on the eggshell (Kuh, Kim 2000).

Because of the eggshell composition, the final pHs of the solutions were higher than the initial value. The precipitation forms of $\mathrm{Cu}^{2+}$ are formed when the $\mathrm{pH}$ value is higher than 6.0. However, the final $\mathrm{pH}$ of the solutions were lower than 6.0 in this study.

\subsection{Effect of temperature}

It was found that the value of $\mathrm{q}_{e}$ increases with increasing the temperature while also increase the release of $\mathrm{Ca}^{2+}$ from the eggshell. When the temperature increases from 25 to $50{ }^{\circ} \mathrm{C}$, the adsorption capacity increased from 5.16 to $9.94 \mathrm{mg} / \mathrm{g}$ indicating that the adsorption was endothermic in nature. At the temperature of $25^{\circ} \mathrm{C}$ and $50{ }^{\circ} \mathrm{C}$, the removal efficiency of $\mathrm{Cu}^{2+}$ ion at equilibrium was $54.5 \%$ and $97.5 \%$, respectively (Fig. 5). It was probably related with the increase of $\mathrm{Ca}^{2+}$ release from the eggshells at higher temperature. Elevating the temperature from 25 to $50{ }^{\circ} \mathrm{C}$, the release of $\mathrm{Ca}^{2+}$ ions into the aqueous solution was increased (about two times). Results might be attributed to the creation of some new active sites on the eggshell and increase in collision frequency between adsorbent and $\mathrm{Cu}^{2+}$ ions at high temperatures. In addition to that, the rise of adsorption with temperature may enlarge the pore size to some extent which may also affect the adsorption capacity (Demirbas et al. 2009).

As mentioned at above, eggshells are composed mainly of calcium carbonate. Calcium ions are bound via ion-exchange and can be thus exchanged by other cations - in this case $\mathrm{Cu}^{2+}$. The experimental results and previous studies confirming that the release of $\mathrm{Ca}^{2+}$ from the various adsorbents were a part of the sorption mechanisms (Sljivic et al. 2009; Arunlertaree et al. 2007; Cheung et al. 2000; Kuh, Kim 2000). This situation can be explained by the fact that at higher temperature, the kinetic energy of $\mathrm{Cu}^{2+}$ is high; therefore, contact between $\mathrm{Cu}^{2+}$ and the eggshell is sufficient, leading to an increase in adsorption efficiencies. The results are consistent with the results of Ghazy et al. (2011). Results indicating that the adsorption of $\mathrm{Cu}^{2+}$ ions was favored at higher temperatures.

\subsection{Effect of sorbent amount}

The dosage of adsorbent is an important parameter in the sorption studies because it provides the capacity of an adsorbent for a given initial concentration of the adsorbate. Figure 6 shows that the absorbability diminished as the adsorbent dosages increased, resulting in that the

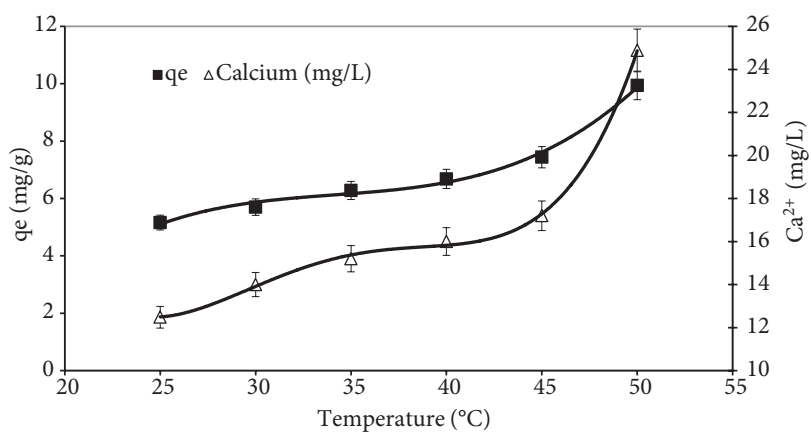

Fig. 5. Temperature effects on $\mathrm{Cu}^{2+}$ adsorption onto eggshell 


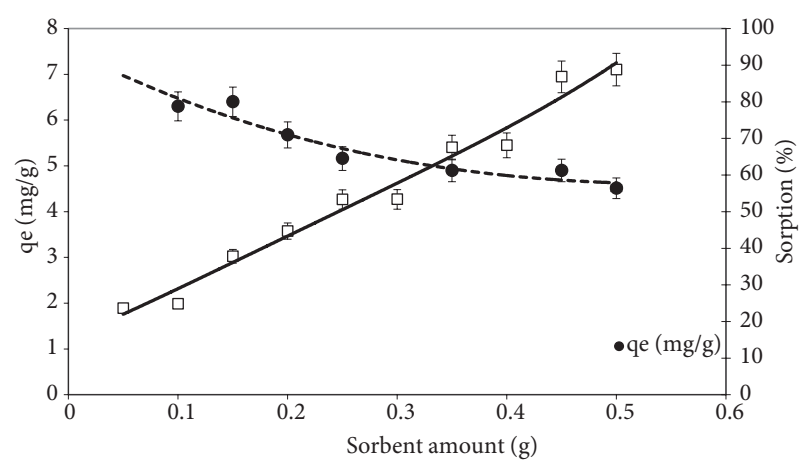

Fig. 6. The effect of sorbent amount on $\mathrm{Cu}^{2+}$ adsorption

amount of $\mathrm{Cu}^{2+}$ adsorbed per unit mass of eggshell decreased. While the amount of $\mathrm{Cu}^{2+}$ sorbed increase from about $24 \%$ to $89 \%$ with an increase in sorbent dosage from 0.05 to $0.5 \mathrm{~g}$, the absorbability of $\mathrm{Cu}^{2+}$ was decreased from about 6.5 to $4.5 \mathrm{mg} / \mathrm{g}$. The decrease in unit adsorption with increase in the dosage of adsorbent was due to adsorption sites remaining unsaturated during the adsorption process (Demirbas et al. 2009). This leads to make a suggestion that, higher $\mathrm{Cu}^{2+}$ concentrations should be tested in conjunction with an appropriate adsorbent dosage in order to determine the optimal eggshell dosage.

\subsection{Modeling of sorption equilibrium depending on $\mathrm{Cu}^{2+}$ concentrations}

Equilibrium relationships between adsorbent and adsorbate are described by adsorption isotherms. After determining the data with respect to the initial concentrations of $\mathrm{Cu}^{2+}$, the results were verified with the Langmuir, Freundlich, Temkin, Dubinin-Radushkevich (D-R) adsorption isotherm models.

Langmuir, (Eqn (5)) Freundlich, (Eqn (7)), Temkin (Eqn (8)), D-R (Eqn (10)) isotherms were plotted by using standard straight-line equations and corresponding two parameters for $\mathrm{Cu}^{2+}$ were calculated from their respective graphs.

A basic assumption of the Langmuir theory is that sorption takes place at specific homogenous sites within the sorbent (Baig et al. 2010). The Langmuir isotherm equation is represented by the following equation (Tsai et al. 2008).

$$
\mathrm{q}_{\mathrm{e}}(\mathrm{mg} / \mathrm{g})=\mathrm{q}_{\mathrm{m}} \frac{\mathrm{K}_{\mathrm{L}} \mathrm{C}_{\mathrm{e}}}{1+\mathrm{K}_{\mathrm{L}} \mathrm{C}_{\mathrm{e}}},
$$

where $\mathrm{q}_{\mathrm{m}}$ indicates the monolayer sorption capacity of adsorbate $(\mathrm{mg} / \mathrm{g})$.

In order to predict the affinity between the waste eggshells and $\mathrm{Cu}^{2+}$ ions, the Langmuir parameters of the dimensionless separation factor $\mathrm{R}_{\mathrm{L}}$ can be used. The value of $R_{L}$ can be calculated by the following equation:

$$
\mathrm{R}_{\mathrm{L}}=\frac{1}{1+\mathrm{K}_{\mathrm{L}} \mathrm{C}_{0}} \text {. }
$$

The value of $R_{L}$ indicates that the shape of the sorption process is; unfavorable $\left(\mathrm{R}_{\mathrm{L}}>1\right)$, linear $\left(\mathrm{R}_{\mathrm{L}}=1\right)$, favorable $\left(0<\mathrm{R}_{\mathrm{L}}<1\right)$ or irreversible $\left(\mathrm{R}_{\mathrm{L}}=0\right)$ (Kilic et al. 2011; Sljivic et al. 2009).

The Freundlich isotherm model is considered to be appropriate for describing both multilayer sorption and sorption on heterogeneous surfaces (Coles, Yong 2006). The Freundlich isotherm equation is represented by the following equation (Tsai et al. 2008).

Freundlich

$$
\mathrm{q}_{\mathrm{e}}(\mathrm{mg} / \mathrm{g})=\mathrm{K}_{\mathrm{Fi}} \mathrm{C}_{\mathrm{e}}^{\frac{1}{\mathrm{n}}} \text {. }
$$

Temkin and Pyzhev considered the effects of indirect adsorbent/adsorbate interactions on adsorption isotherms (Kilic et al. 2011).

Temkin

$$
\mathrm{q}_{\mathrm{e}}(\mathrm{mg} / \mathrm{g})=\mathrm{B} \ln \mathrm{A}_{\mathrm{T}}+\mathrm{B} \ln \mathrm{C}_{\mathrm{e}} .
$$

The linear form of Temkin isotherm equation is as follows:

$$
\mathrm{q}_{\mathrm{e}}(\mathrm{mg} / \mathrm{g})=\mathrm{B} \ln \mathrm{K}_{\mathrm{T}}+\ln \mathrm{C}_{\mathrm{e}} \text {, }
$$

where: $\mathrm{B}=\mathrm{RT} / \mathrm{b}_{\mathrm{T}}$ (Temkin constant related to heat of sorption, $\mathrm{J} / \mathrm{mol}$ ); $1 / \mathrm{b}_{\mathrm{T}}$ indicates the adsorption potential of the adsorbent

The experimental data were also analyzed using the Dubinin-Radushkevich (D-R) isotherm model to determine the nature of biosorption processes as physical or chemical (Baig et al. 2010) by applying the following equation:

$$
\ln \mathrm{q}_{\mathrm{e}}=\ln \mathrm{q}_{\max }-\beta \varepsilon^{2},
$$

and $\varepsilon$ can be correlated as:

$$
\varepsilon=\mathrm{RT} \ln \left(1+\frac{1}{\mathrm{C}_{\mathrm{e}}}\right) .
$$

The constants $\beta$ and $\mathrm{E}$ are the mean free energy and sorption per molecule of the sorbate, respectively. They can be computed using the following relationship (Kose, Kivanc 2011).

$$
\mathrm{E}=\frac{1}{\sqrt{-2 \beta}} .
$$

Sorption parameters for the isotherms are as follows: $\mathrm{K}_{\mathrm{L}}$ (L/mg) Langmuir constant related to the energy of sorption; $\mathrm{K}_{\mathrm{Fi}}(\mathrm{L} / \mathrm{mg})$ Freundlich constant related to sorption capacity of adsorbent; $\mathrm{q}_{\max }(\mathrm{mg} / \mathrm{g})$ is the maximum biosorption capacity of D-R. $b_{T}$ and $A_{T}(L / m g)$ Temkin isotherm parameters; $\mathrm{R}$ is the gas constant $(8.314$ joule.mol/K); $\mathrm{T}$ is the absolute temperature $(\mathrm{K})$.

The constants of all isotherms equation are presented in Table 1. As a result of the experiments, the highest correlation coefficient of 0.999 was determined using the Langmuir model than the others; it is suggesting that the $\mathrm{Cu}^{2+}$ ions were adsorbed onto the eggshell in a monolayer. Additionally, the calculated $\mathrm{q}_{\mathrm{cal}}$ value of the Langmuir 
model equation corresponded well with the experimentally obtained. The amounts of sorbed $\mathrm{Cu}^{2+}$ increased with the increase of initial $\mathrm{Cu}^{2+}$ concentration in the solution until the equilibrium was achieved. Further increase, the removal of $\mathrm{Cu}^{2+}$ became independent of the initial cation concentration, due to occupancy of all active sites on the adsorbent surface (Sljivic et al. 2009). The experimentally obtained maximum capacity for monolayer saturation was $5.05 \mathrm{mg} \mathrm{Cu}^{2+} / \mathrm{g}$ eggshell at $25 \pm 1^{\circ} \mathrm{C}$. The calculated $R_{\mathrm{L}}$ values were between $2.27 \times 10^{-3}$ and $11 \times 10^{-2}$ which indicated that the $\mathrm{Cu}^{2+}$ sorption by waste eggshell sample was favorable.

Table 1. Correlation coefficient and sorption parameters for various models

\begin{tabular}{|c|c|c|c|}
\hline Model & Equation & \multicolumn{2}{|c|}{ Sorption Parameters } \\
\hline \multirow{3}{*}{$\begin{array}{l}\text { Freund- } \\
\text { lich }\end{array}$} & \multirow{3}{*}{$\mathrm{q}_{\mathrm{e}}(\mathrm{mg} / \mathrm{g})=\mathrm{K}_{\mathrm{Fi}} \mathrm{C}_{\mathrm{e}}^{\frac{1}{\mathrm{n}}}$} & $\mathrm{R}^{2}$ & 0.6958 \\
\hline & & $\mathrm{n}$ & 15.9 \\
\hline & & $\mathrm{K}_{\mathrm{F}}$ & 4.08 \\
\hline \multirow{4}{*}{ Langmuir } & \multirow{4}{*}{$\mathrm{q}_{\mathrm{e}}(\mathrm{mg} / \mathrm{g})=\mathrm{q}_{\mathrm{m}} \frac{\mathrm{K}_{\mathrm{L}} \mathrm{C}_{\mathrm{e}}}{1+\mathrm{K}_{\mathrm{L}} \mathrm{C}_{\mathrm{e}}}$} & $\mathrm{R}^{2}$ & 0.9995 \\
\hline & & $\mathrm{R}_{\mathrm{L}}$ & $\begin{array}{c}11 \times 10^{-2} \\
2.27 \times 10^{-3}\end{array}$ \\
\hline & & $\mathrm{q}_{\mathrm{m}}$ & 5.05 \\
\hline & & $\mathrm{K}_{\mathrm{L}}$ & 70,7 \\
\hline \multirow{3}{*}{ Temkin } & \multirow{3}{*}{$\begin{array}{l}\mathrm{q}_{\mathrm{e}}(\mathrm{mg} / \mathrm{g})=\mathrm{B}_{\mathrm{T}} \ln \mathrm{A}_{\mathrm{T}}+\mathrm{B}_{\mathrm{T}} \\
\ln \mathrm{C}_{\mathrm{e}}\end{array}$} & $\mathrm{R}^{2}$ & 0.720 \\
\hline & & $\mathrm{b}_{\mathrm{T}}$ & 7485 \\
\hline & & $\mathrm{A}_{\mathrm{T}}(\mathrm{L} / \mathrm{g})$ & 248 \\
\hline \multirow{4}{*}{$\mathrm{R}-\mathrm{D}$} & \multirow{4}{*}{$\ln \mathrm{q}_{\mathrm{e}}=\ln \mathrm{q}_{\max }-\beta \varepsilon^{2}$} & $\mathrm{R}^{2}$ & 0.994 \\
\hline & & $\mathrm{q}_{0}(\mathrm{mg} / \mathrm{g})$ & 5.083 \\
\hline & & $\beta\left(\mathrm{mol}^{2} / \mathrm{j}^{2}\right)$ & -0.063 \\
\hline & & $\mathrm{E}(\mathrm{kj} / \mathrm{mol})$ & 2.82 \\
\hline
\end{tabular}

\subsection{Kinetics of sorption}

In order to determine the uptake rate of adsorbate at the solid-phase interface, adsorption kinetics study is important. Various kinetic models including, pseudo first and second order kinetics, intraparticle diffusion, and Elovich were applied to the experimental data in order to investigate the mechanisms of eggshell sorption.

The adsorption kinetic models were investigated at three adsorbate dosages of 15,25 , and $35 \mathrm{mg} \mathrm{Cu}^{2+} / \mathrm{L}$. Lagergren and Annadurai and Krishan presented the first (Eqn (13)) and second order (Eqn (14)) rates expression for the first and second pseudo order kinetics (Chiou, Li 2002; Rao et al. 2010; Chairat et al. 2005):

$$
\begin{gathered}
\log \left(\mathrm{q}_{\mathrm{e}}-\mathrm{q}_{\mathrm{t}}\right)=\log \mathrm{q}_{\mathrm{e}}-\frac{\mathrm{k}_{1}}{2.303} \mathrm{t} ; \\
\frac{1}{\mathrm{q}_{\mathrm{t}}}=\frac{1}{\mathrm{k}_{2} \mathrm{q}_{\mathrm{e}}^{2}}+\frac{\mathrm{t}}{\mathrm{q}_{\mathrm{e}}},
\end{gathered}
$$

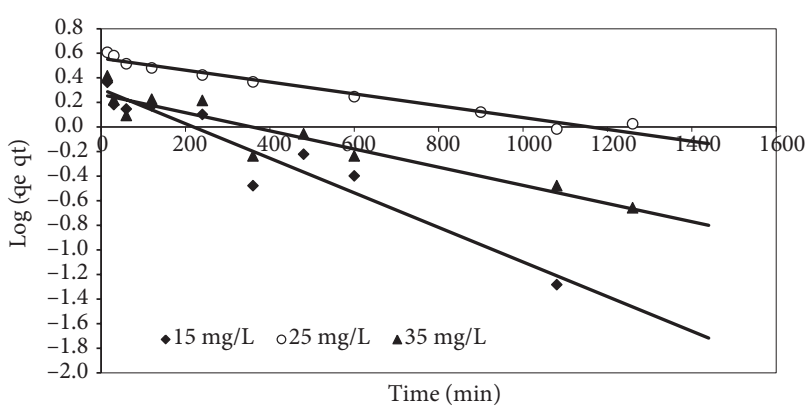

Fig. 7. Pseudo-first order kinetics of $\mathrm{Cu}^{2+}$ adsorption onto the eggshell at various adsorbate amounts

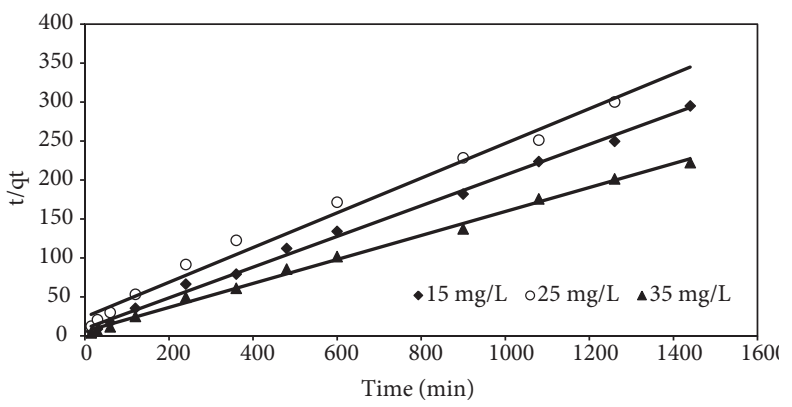

Fig. 8. Pseudo-second order kinetics of $\mathrm{Cu}^{2+}$ adsorption onto the eggshell at various adsorbate amounts

where: $\mathrm{q}_{\mathrm{e}}$ and $\mathrm{q}_{\mathrm{t}}(\mathrm{mg} / \mathrm{g})$ are the amount of $\mathrm{Cu}^{2+}$ adsorbed onto the eggshell at equilibrium and at time $\mathrm{t}(\mathrm{min})$, respectively, the first and second order rate constants $(\mathrm{min})^{-1}$ are $\mathrm{k}_{1}$ and $\mathrm{k}_{2}(\mathrm{mg} / \mathrm{g} \cdot \mathrm{min})$, respectively. In order to determine the value of $k_{1}$ and $q_{e}$, the plot of $\log \left(q_{e}-q_{t}\right)$ against $t$ is employed for the first pseudo order kinetic constants. The second pseudo order kinetics constants $\mathrm{k}_{2}$ and $\mathrm{q}_{\mathrm{e}}$ are calculated by the slope and intercept of (t/qt) versus $t$ (Figs 7 and 8 ).

The initial sorption rate $\mathrm{h}(\mathrm{mg} / \mathrm{g} \cdot \mathrm{min})$ is determined by using the Eqn (15):

$$
\mathrm{h}=\mathrm{k}_{2} \times \mathrm{q}_{\mathrm{e}}^{2} .
$$

The uptake of adsorbate by the sorbent from solutions involves bulk, film, and intraparticle diffusion in the solid phase and within the pores, and finally adsorption on the sites. In order to determine the rate-controlling step, intraparticle diffusion model was applied to adsorption kinetic data by applying the Eqn (16) (Ghasemi et al. 2012).

$$
\mathrm{q}_{\mathrm{t}}=\mathrm{k}_{\mathrm{id}} \mathrm{t}^{\frac{1}{2}}+\mathrm{C},
$$

where: $q_{t}$ is the amount of $\mathrm{Cu}^{2+}$ ions adsorbed onto the eggshell at time $t$ and $k_{\mathrm{id}}(\mathrm{g} / \mathrm{mg} \cdot \mathrm{min})$ is the intraparticle diffusion rate constant and $\mathrm{C}$ presents an idea on the thickness of the boundary layer (Ahmad et al. 2010).

The value of rate constant of Morris-Weber transport, $\mathrm{K}_{\mathrm{id}}$, calculated from the slope of the linear plot are shown in Figure 9. 


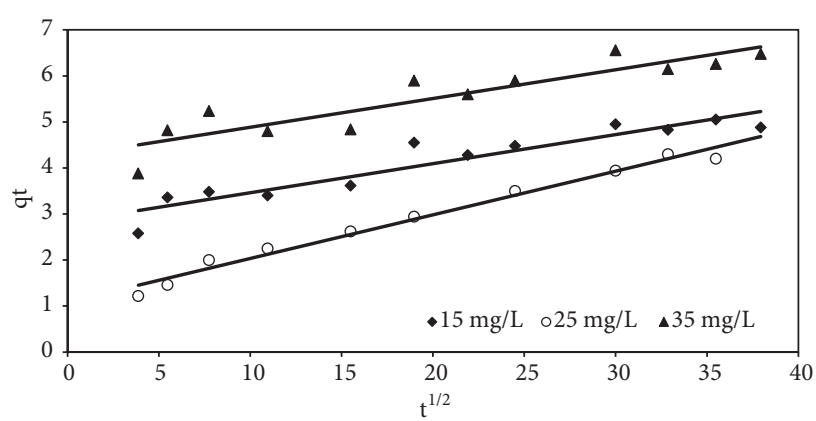

Fig. 9. Intraparticle diffusion for the adsorption of $\mathrm{Cu}^{2+}$ onto the eggshell at various adsorbate amounts

The integrated Elovich equation is given as:

$$
\mathrm{q}_{\mathrm{t}}=\frac{1}{\beta} \ln \alpha \beta+\frac{1}{\beta} \ln \mathrm{t},
$$

where: $\alpha$ (mg/g.min) is the initial sorption rate and $\beta$ (g/ $\mathrm{mg}$ ) is related to the extent of surface coverage and activation energy for chemisorption (Ozacar, Sengil 2005). A plot of $q_{t}$ versus $\ln (t)$ should yield a linear relationship with a slope of $(1 / b)$ and an intercept of $(1 / b) \ln (\alpha b)$ (Demirbas et al. 2009). The values of rate constants of Elovich model are shown in Figure 10.

The values of $\mathrm{q}_{\mathrm{e}}, \mathrm{k}_{1}, \mathrm{k}_{2}, \alpha$, and $\beta$ with the correlation coefficient $\left(R^{2}\right)$ for various eggshell amounts of 15,25 , and $35 \mathrm{mg} / \mathrm{L}$ were calculated by their respected plots and the results are presented in Table 2.

Table 2. Kinetic parameters for the sorption of $\mathrm{Cu}^{2+}$ onto the eggshell

\begin{tabular}{|c|c|c|c|c|c|c|c|c|}
\hline \multirow{2}{*}{$\begin{array}{l}\text { Conc } \\
\mathrm{mg} / \mathrm{L}\end{array}$} & \multirow{2}{*}{$\begin{array}{c}\mathrm{q}_{\mathrm{e}, \exp } \\
\mathrm{mg} / \mathrm{g}\end{array}$} & \multicolumn{3}{|c|}{ Pseudo-first-order } & \multicolumn{4}{|c|}{ Pseudo-second-order } \\
\hline & & $q_{e, \text { al }}$ & $\mathrm{k}_{1} \cdot 10^{-3}$ & $\mathrm{R}^{2}$ & $\mathrm{q}_{e, \text { cal }}$ & $\mathrm{k}_{2} \cdot 10^{-3}$ & $\mathrm{R}^{2}$ & $\mathrm{~h}$ \\
\hline 15 & 4.88 & 2.035 & 3.22 & 0.92 & 5.08 & 4.15 & 0.99 & 0.107 \\
\hline 25 & 5.26 & 3.62 & 1.15 & 0.97 & 4.49 & 2.04 & 0.98 & 0.041 \\
\hline 35 & 6.48 & 1.836 & 1.61 & 0.88 & 6.51 & 4.13 & 0.99 & 0.175 \\
\hline \multirow{2}{*}{$\begin{array}{l}\text { Conc } \\
\mathrm{mg} / \mathrm{L}\end{array}$} & \multirow{2}{*}{$\begin{array}{r}\mathrm{q}_{e, \exp } \\
\mathrm{mg} / \mathrm{g}\end{array}$} & \multicolumn{3}{|c|}{ Intraparticle diffusion } & \multicolumn{4}{|c|}{ Elovich } \\
\hline & & $\mathrm{k}_{\mathrm{p}}$ & $\mathrm{R}^{2}$ & $\alpha$ & $\beta$ & $\mathrm{R}^{2}$ & & \\
\hline 15 & 4.88 & 0.0632 & 0.911 & 6.83 & 1.99 & 0.913 & & \\
\hline 25 & 5.26 & 0.0949 & 0.981 & 2.634 & 1.423 & 0.966 & & \\
\hline 35 & 6.48 & 0.0624 & 0.819 & 36.2 & 2.03 & 0.838 & & \\
\hline
\end{tabular}

On changing the initial concentration of $\mathrm{Cu}^{2+}$ in the solutions from 15 to $35 \mathrm{mg} / \mathrm{L}$, the amount of $\mathrm{Cu}^{2+}$ adsorbed onto the eggshell increased experimentally. The correlation coefficient for the pseudo-second orders were relatively higher than the other kinetic models and the experimental $\mathrm{q}_{\mathrm{e}}(4.88 \mathrm{mg} / \mathrm{g}$ and $6.48 \mathrm{mg} / \mathrm{g})$ values are also very close to the calculated $\mathrm{q}_{e}$ values $(5.08-6.51 \mathrm{mg} / \mathrm{g})$. The rate constant slightly decreases with an increasing of initial $\mathrm{Cu}^{2+}$ concentration while the initial sorption rate increases with an increasing of initial $\mathrm{Cu}^{2+}$ concentration for the pseudo second-order model. The similar

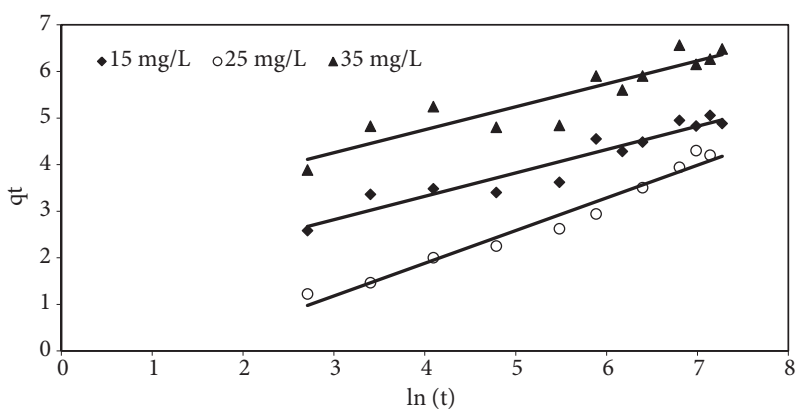

Fig. 10. Elovich Model for $\mathrm{Cu}^{2+}$ adsorption onto the eggshell at various adsorbate amounts

phenomena have also reported in sorption of $\mathrm{Cu}^{2+}$ onto the biowaste materials (Sljivic et al. 2009; Kizilkaya et al. 2010; Ahmad et al. 2010; Demirbas et al. 2009). Increase of $q_{e}$ value is a result of the increase in the driving force of the concentration gradient with the increase in the initial $\mathrm{Cu}^{2+}$ concentration. Therefore a higher initial concentration of $\mathrm{Cu}^{2+}$ ions may increase the adsorption capacity of eggshell. It means that the biosorption is highly dependent on initial concentration of metal ion.

The results are indicated that the sorption perfectly complies with pseudo-second order reaction and the sorption of $\mathrm{Cu}^{2+}$ onto the eggshell appeared to be controlled by the chemisorption process.

Several biosorbents have been used to remove $\mathrm{Cu}^{2+}$ from aqueous solutions. A comparison of the adsorbent capacity is presented in Table 3. As can be seen from the table that eggshell shows the comparable sorption capacity for $\mathrm{Cu}^{2+}$ with respect to the other biosorbents.

Table 3. Comparison of various biosorbent for $\mathrm{Cu}^{2+}$ removal

\begin{tabular}{lcl}
\hline \multicolumn{1}{c}{ Biosorbent } & $\mathrm{mg} / \mathrm{g}$ & \multicolumn{1}{c}{ References } \\
\hline Fish bones & 150.7 & Kizllkaya et al. 2010 \\
Green alga Spirogyra & 133.3 & Gupta et al. 2006 \\
Garden grass & 58.34 & Hossain et al. 2012 \\
Iron oxide coated & 44.843 & Ahmad et al. 2010 \\
eggshell powder & 30.30 & Onal et al. 2008 \\
Sunflower shell & 8.452 & Larous et al. 2005 \\
Sawdust & 8.14 & Rocha et al. 2009 \\
Rice straw & 6.950 & Rozaini et al. 2010 \\
Modified mangrove & 6.48 & This study \\
barks & 5.40 & Šciban et al. 2008 \\
Eggshell & 5.03 & Vijayarghavan et al. 2005 \\
Soybean straw & 4.96 & Onal et al. 2008 \\
\hline Eggshell & 4.64 & Pehlivan et al. 2009 \\
Orange skin & 4.448 & Šciban et al. 2008 \\
Barley straws & 3.749 & Šciban et al. 2008 \\
Wheat straw & 2.16 & Šciban et al. 2008 \\
Corn stalk & & \\
Corn cob &
\end{tabular}




\section{Conclusions}

The present experimental study results showed that the waste eggshells might be applicable successfully as a sorbent of cupper ions from aqueous solution. As a conclusion:

1) The adsorption of cupper onto the waste eggshell was found to be initial $\mathrm{Cu}^{2+}$ concentration, $\mathrm{pH}$, temperature, mixing time, and adsorbate dosage depended.

2) The optimum $\mathrm{pH}$ value for the experimental study was determined as 4.0 .

3) Increasing the temperature, $q_{e}$ value increased with the increase the release of $\mathrm{Ca}^{2+}$ from the eggshell.

4) Sorption of eggshell onto the eggshell was well described by Langmuir model.

5) Results indicated that pseudo second-order kinetic model, which is an agreement with a chemisorption mechanism, provided the best correlation of the experimental data.

\section{Acknowledgment}

This study was supported by The Research Fund of Cumhuriyet University (CUBAP) under Grant No. M-459, Sivas, Turkey.

\section{References}

Ahmad, R.; Kumar, R.; Haseeb, S. 2010. Adsorption of $\mathrm{Cu}^{2+}$ from aqueous solution onto iron oxide coated eggshell powder: evaluation of equilibrium, isotherms, kinetics, and regeneration capacity, Arabian Journal of Chemistry 5(3): 353-359. http://dx.doi.org/10.1016/j.arabjc.2010.09.003

APHA, 1998. Standard methods for the examination of water and wastewater, $20^{\text {th }}$ ed. American Public Health Association/ American Water Works Association/Water Environment Federation, Washington, DC, USA.

Arunlertaree, C.; Kaewsomboon, W.; Kumsopa; Pokethitiyook, P.; Panyawathanakit, P. 2007. Removal of lead from battery manufacturing wastewater by egg shell, Songklanakarin Journal of Science and Technology 29(3): May - Jun: 857868.

Baig, J. A.; Kazi, T. G.; Shah, A. Q.; Kandhro, G. A.; Afridi, H. I.; Khan, S.; Kolachi, N. F. 2010. Biosorption studies on powder of stem of Acacia nilotica: removal of arsenic from surface water, Journal of Hazardous Materials 178(1-3): 941-948. http://dx.doi.org/10.1016/j.jhazmat.2010.02.028

Chairat, M.; Rattanaphani, S.; Bremner, J. B.; Rattanaphani, V. 2005. An adsorption and kinetic study of lac dyeing on silk, Dyes and Pigments 64(3): 231-241. http://dx.doi.org/10.1016/j.dyepig.2004.06.009

Cheung, C. W.; Porter, J. F.; McKay, G. 2000. Sorption kinetics for the removal of copper and zinc from effluents using bone char, Separation and Purification Technology 19(1-2): 55-64. http://dx.doi.org/10.1016/S1383-5866(99)00073-8

Chiou, M. S.; Li, H. S. 2002. Equilibrium and kinetic modeling of adsorption of reactive dye on cross-linked chitosan beads, Journal of Hazardous Materials 93(2): 223-248. http://dx.doi.org/10.1016/S0304-3894(02)00030-4
Chojnacka, K. 2005. Biosorption of Cr (III) ions by eggshells, Journal of Hazardous Materials 121(1-3): 167-173. http://dx.doi.org/10.1016/j.jhazmat.2005.02.004

Coles, C. A.; Yong, R. N. 2006. Use of equilibrium and initial metal concentrations in determining Freundlich isotherms for soils and sediments, Engineering Geology 85(1-2): 19-25. http://dx.doi.org/10.1016/j.enggeo.2005.09.023

Demirbas, E.; Dizge, E.; Sulak, M. T.; Kobya, M. 2009. Adsorption kinetics and equilibrium of copper from aqueous solutions using hazelnut shell activated carbon, Chemical Engineering Journal 148(2-3): 480-487. http://dx.doi.org/10.1016/j.cej.2008.09.027

Ghasemi, Z.; Seif, A.; Ahmadi, T. S.; Zargar, B.; Rashidi, F.; Rouzbahani, G. M. 2012. Thermodynamic and kinetic studies for the adsorption of $\mathrm{Hg}(\mathrm{II})$ by nano- $\mathrm{TiO}_{2}$ from aqueous solution, Advanced Powder Technology 23(2): 148-156. http://dx.doi.org/10.1016/j.apt.2011.01.004

Ghazy, S. El-S.; El-Asmy, A. A.-H.; El-Nokrashy, A. M. 2011. Batch removal of nickel by eggshell as a low cost sorbent, International Journal of Industrial Chemistry 2(4): 242-252.

Gupta, V. K.; Rastogi, A.; Saini, V. K.; Jain, N. 2006 Biosorption of copper(II) from aqueous solutions by Spirogyra species, Journal of Colloid and Interface Science 296(1): 59-63. http://dx.doi.org/10.1016/j.jcis.2005.08.033

Hossain, M. A.; Ngo, H. H.; Guo, W. S.; Setiati, T. 2012. Adsorption and desorption of copper(II) ions onto garden grass, Bioresource Technology 121: 386-395. http://dx.doi.org/10.1016/j.biortech.2012.06.119

Jai, P. H.; Wook, J. S.; Kyu, Y. J.; Gil, K. B.; Mok, L. S. 2007. Removal of heavy metals using waste eggshell, Journal of Environmental Science 19(12): 1436-1441. http://dx.doi.org/10.1016/S1001-0742(07)60234-4

Kilic, M.; Varol, E. A.; Putun, A. E. 2011. Adsorptive removal of phenol from aqueous solutions on activated carbon prepared from tobacco residues: equilibrium, kinetics and thermodynamics, Journal of Hazardous Materials 189(1-2): 397-403. http://dx.doi.org/10.1016/j.jhazmat.2011.02.051

Kizilkaya, B.; Tekinay, A. A.; Dilgin, Y. 2010. Adsorption and removal of $\mathrm{Cu}$ (II) ions from aqueous solution using pretreated fis bones, Desalination 264(1-2): 37-47. http://dx.doi.org/10.1016/j.desal.2010.06.076

Kose, T. E.; Kivanc, B. 2011. Adsorption of phosphate from aqueous solutions using calcined waste eggshell, Chemical Engineering Journal 178: 34-39. http://dx.doi.org/10.1016/j.cej.2011.09.129

Kuh, S. E.; Kim, D. S. 2000. Removal characteristics of cadmium ion by waste egg shell, Environmental Technology 21(8): 883-890. http://dx.doi.org/10.1080/09593330.2000.9618973

Larous, S.; Meniai, A.-H.; Lehocine, M. B. 2005. Experimental study of the removal of copper from aqueous solutions by adsorption using sawdust, Desalination 185(1-3): 483-490. http://dx.doi.org/10.1016/j.desal.2005.03.090

Li, S. Z.; Wua, P. X. 2010. Characterization of sodium dodecyl sulfate modified iron pillared montmorillonite and its application for the removal of aqueous $\mathrm{Cu}(\mathrm{II})$ and $\mathrm{Co}(\mathrm{II})$, Journal of Hazardous Materials 173(1-3): 62-70. http://dx.doi.org/10.1016/j.jhazmat.2009.08.047

Onal, O.; Ozcelik, E.; Benli, S., et al. 2008. Adsorption of $\mathrm{Fe}^{3+}$ and $\mathrm{Cu}^{2+}$ on orange skin and sunflower shell, in $4^{\text {th }}$ European BioRemediation Conference, 3-6 September, 2008, Chania, Crete, Greece. 
Ozacar, M.; Sengil, I. A. 2005. A kinetic study of metal complex dye sorption onto pine sawdust, Process Biochemistry 40(2): 565-572. http://dx.doi.org/10.1016/j.procbio.2004.01.032

Pehlivan, E.; Ozkan, A. M.; Dinc, S.; Parlayici, S. 2009. Adsorption of $\mathrm{Cu}^{2+}$ and $\mathrm{Pb}^{2+}$ ion on dolomite powder, Journal of Hazardous Materials 167(1-3): 1044-1049. http://dx.doi.org/10.1016/j.jhazmat.2009.01.096

Rao, H. J.; Kalyani, G.; Rao, K. V.; Kumar, T. A.; Mariadas, K.; Kumar, Y. P.; Vijetha, P.; Pallavi, P.; Sumalatha, B.; Kumaraswamy, K. 2010. Kinetic studies on biosorption of lead from aqueous solutions using egg shell powder, International Journal of Biotechnology and Biochemistry 6: 957-968.

Rocha, G. C.; Zai, D. A. M.; Alfaya, R. V. S. 2009. Use of rice straw as biosorbent for removal of $\mathrm{Cu}(\mathrm{II}), \mathrm{Zn}(\mathrm{II}), \mathrm{Cd}(\mathrm{II})$ and $\mathrm{Hg}(\mathrm{II})$ ions in industrial effluents, Journal of Hazardous Materials 166(1): 383-388.

http://dx.doi.org/10.1016/j.jhazmat.2008.11.074

Rozaini, C. A.; Jain, K.; Oo, C. W.; Tan, K. W.; Tan, L. S.; Azraa, A.; Tong, K. S. 2010. Optimization of nickel and copper ions removal by modified mangrove barks, International Journal of Chemical Engineering and Applications 1(1): 84-89. http://dx.doi.org/10.7763/IJCEA.2010.V1.14

Šciban, M.; Klašnja, M.; Škrbic, M. 2008. Adsorption of copper ions from water by modified agricultural by-products, Desalination 229(1-3): 170-180. http://dx.doi.org/10.1016/j.desal.2007.08.017

Sljivic, M.; Smiciklas, I.; Plecas, I., et al. 2009. The influence of equilibration conditions and hydroxyapatite physico-chemical properties onto retention of $\mathrm{Cu}^{2+}$ ion, Chemical Engineering Journal 148(1): 80-88.

http://dx.doi.org/10.1016/j.cej.2008.08.003
Tsai, W. T.; Yang, J. M.; Lai, C. W.; Cheng, Y. H.; Lin, C. C.; Yeh, C. W. 2006. Characterization and adsorption properties of eggshells and eggshell membrane, Bioresource Technology 97(3): 488-493. http://dx.doi.org/10.1016/j.biortech.2005.02.050

Tsai, W.-T.; Hsien, K.-J.; Hsu, H.-C. ; Lin, C.-M.; Lin, K.-Y.; Chiu, C.-H. 2008. Utilization of ground eggshell waste as an adsorbent for the removal of dyes from aqueous solution, Bioresource Technology 99(6): 1623-1629. http://dx.doi.org/10.1016/j.biortech.2007.04.010

Vijayaraghavan, K.; Jegan, J.; Palanivelu, K., et al. 2005. Removal and recovery of copper from aqueous solution by eggshell in a packed column, Mineral Engineering 18(5): 545-547. http://dx.doi.org/10.1016/j.mineng.2004.09.004

Yeddou, N.; Bensmaili, A. 2007. Equilibrium and kinetic modeling of iron adsorption by eggshells in a batch system: effect of temperature, Desalination 206(1-3): 127-134. http://dx.doi.org/10.1016/j.desal.2006.04.052

Zhang, S.; Guo, Z.; Xu, J., et al. 2011. Effect of environmental conditions on the sorption of radiocobalt from aqueous solution to treated eggshell as biosorbent, Journal of Radioanalytical and Nuclear Chemistry 288(1): 121-130. http://dx.doi.org/10.1007/s10967-010-0895-8

Zheng, W.; Li, X.-M.; Yang, Q., et al. 2007. Adsorption of Cd(II) and $\mathrm{Cu}(\mathrm{II})$ from aqueous solution by carbonate hydroxylapatite derived from eggshell waste, Journal of Hazardous Materials $147(1-2): 534-539$. http://dx.doi.org/10.1016/j.jhazmat.2007.01.048

Ayben POLAT. She is an Environmental Engineer at the Department of Environmental Engineering, Cumhuriyet University, Sivas. Her research interest includes adsorption.

Sukru ASLAN. Dr Lecturer at the Department of Environmental Engineering, Cumhuriyet University, Sivas. His research interests include biological nutrient removal, sorption. 